Article

\title{
Influence of Citrus Scion/Rootstock Genotypes on Arbuscular Mycorrhizal Community Composition under Controlled Environment Condition
}

\author{
Fang Song ${ }^{1, *} \mathbb{C}$, Fuxi Bai ${ }^{1}$, Juanjuan Wang ${ }^{2}$, Liming $W_{u}{ }^{1}$, Yingchun Jiang ${ }^{1}$ and Zhiyong Pan ${ }^{3}$ \\ 1 Institute of Fruit and Tea, Hubei Academy of Agricultural Sciences, Wuhan 430064, China; \\ baifuxi_kiwi@163.com (F.B.); wuliming2005@126.com (L.W.); jyc6512@aliyun.com (Y.J.) \\ 2 Institute National Agro-Technical Extension and Service Center (NATESC), Ministry of Agriculture, \\ Beijing 100000, China; wangjuanjuan@agri.gov.cn \\ 3 College of Horticulture and Forestry Sciences, Huazhong Agricultural University, Wuhan 430070, China; \\ zypan@mail.hzau.edu.cn \\ * Correspondence: fsong_ray@163.com
}

Received: 23 June 2020; Accepted: 14 July 2020; Published: 16 July 2020

\begin{abstract}
Citrus is vegetatively propagated by grafting for commercial production, and most rootstock cultivars of citrus have scarce root hairs, thus heavily relying on mutualistic symbiosis with arbuscular mycorrhizal fungi (AMF) for mineral nutrient uptake. However, the AMF community composition, and its differences under different citrus scion/rootstock genotypes, were largely unknown. In this study, we investigated the citrus root-associated AMF diversity and richness, and assessed the influence of citrus scion/rootstock genotypes on the AMF community composition in a controlled condition, in order to exclude interferences from environmental factors and agricultural practices. As a result, a total of 613,408 Glomeromycota tags were detected in the citrus roots, and 46 AMF species were annotated against the MAARJAM database. Of these, 39 species belonged to Glomus, indicating a dominant role of the Glomus AMF in the symbiosis with citrus. PCoA analysis indicated that the AMF community's composition was significantly impacted by both citrus scion and rootstock genotypes, but total samples were clustered according to rootstock genotype rather than scion genotype. In addition, AMF $\alpha$ diversity was significantly affected merely by rootstock genotype. Thus, rootstock genotype might exert a greater impact on the AMF community than scion genotype. Taken together, this study provides a comprehensive insight into the AMF community in juvenile citrus plants, and reveals the important effects of citrus genotype on AMF community composition.
\end{abstract}

Keywords: AMF community composition; citrus; scion/rootstock genotype; Illumina Miseq sequencing; PCoA.

\section{Introduction}

Arbuscular mycorrhizal symbiosis (AMS), a widespread mutualistic relationship between more than $72 \%$ of vascular plants and arbuscular mycorrhizal fungi (AMF), dates back to more than 400 million years ago [1]. All AMF belong to the phylum of Glomeromycota, which contains about 288 described species or 1700 putative species [2]. AMF can facilitate the uptake of water and mineral nutrients, such as phosphorus and nitrogen, from soil through the hypha network, and thus it can promote plant growth and development, and its tolerance to biotic/abiotic stress [3-7]. In exchange, the plant provides photosynthate, such as lipids, to fungi to complete the fungal life cycle [8-10]. Citrus roots have scarce root hairs, thus they heavily rely on AMF for absorbing mineral nutrients from soil [11]. Therefore, controlling AMF communities colonized in roots has been considered as an 
important measure in order to promote the sustainable development of the citrus industry by reducing the application of fertilizer [12,13].

Considering the significant roles of AMF in the ecosystem, the compositions of AMF communities have been determined through high-throughput DNA sequencing technologies in various natural and agricultural environments, including plateau, desert, forestland, grassland, shrubland and farmland [14-20]. According to the previous studies, AMF community composition is mainly affected by spatial scales, soil properties, climates and agricultural practices [18,20-23]. In addition to these abiotic factors, the AMF community is also impacted by host plants. Because the contributions made by different mycorrhiza to plants are varied [24,25], the host plants are able to shape the AMF communities with their functional traits [26,27], and the effects of the host plants on the AMF communities could be observed even at the genotype level [28].

Grafting is a classic technique that joins the rootstock of one plant to the scion of another, and it plays a significant role in increasing the yield, fruit quality, abiotic stress resistance and pathogen resistance of citrus plants [29,30]. Although some pioneering studies have investigated the effects of scion and rootstock genotypes on the bacterial community in grafted plants [31,32], the research on their effect on the AMF community is still limited. One of our previous studies has reported that the citrus root-associated AMF community is mainly affected by habitats, but citrus genotypes also played a minor role in shaping the AMF community [33]. However, most existing studies were conducted in field conditions, and it was difficult to exclude the huge interferences of the environment and agricultural practices.

In this study, citrus plants with different scion/rootstock genotype combinations were planted in the same field in the greenhouse, in order to exclude the interference from environment factors and all the agricultural practices (e.g., irrigation, fertilization, shoot cutting and weeding). Based on high-throughput sequencing of the $18 \mathrm{~S}$ ribosomal RNA (rRNA) gene fragments of AMF amplified from the DNA samples prepared from citrus roots, we examined the citrus root-associated AMF community composition in a greenhouse, as well as its differences under different scion genotypes and rootstock genotypes.

\section{Results}

\subsection{Overall Citrus AMF Taxonomic Richness}

In this study, the 18S SSU rRNA (a small subunit region of ribosomal RNA) gene fragments of 18 root DNA samples, from six different scion/rootstock genotype plants grown in the same field, were investigated to reveal the effects of citrus scion/rootstock genotypes on the AMF community in a controlled condition. MISeq high-throughput sequencing indicated that a total of 1,440,324 raw reads were produced, 1,278,760 reads of which were considered as clean reads after screening. These two pair-end clean reads were then assembled into 630,728 clean tags, of which 614,590 clean tags could be assigned to the sequences deposited in the SILVA database (v108, [34]). These clean tags could be further divided into six distinct taxonomic groups based on the amplified SSU rRNA gene tags (Table 1). As expected, most tags amplified with the primer pair AMV4.5NF/AMDGR (613,408 tags, accounting for $99.81 \%$ of the total tags) belonged to Glomeramycota, which were also considered to be arbuscular mycorrhizal fungi (AMF). Some non-AMF sequences were also detected in this study, including Basidiomycota (794 tags, accounting for $0.13 \%$ of the total tags), Ascomycota $(41,0.01 \%)$ and Chytridiomycota $(13,0.00 \%)$. A small proportion of the tags $(334,0.05 \%)$ could not be unambiguously assigned to any of the above phyla (Table 1). To better clarify the genetic diversity of the AMF community associated with the citrus root, 614,590 clean tags were further clustered into 132 operational taxonomic units (OTUs), based on $97 \%$ sequence similarity. The 87 OTUs (accounting for $65.91 \%$ of the total OTUs) belonged to Glomeramycota, followed by Basidiomycota $(13,9.85 \%)$, Ascomycota $(8,6.06 \%)$, Chytridiomycota $(1,1.76 \%)$, and the remaining 23 OTUs $(17.42 \%)$ belonged to the unclassified group (Table 1). 
Table 1. Proportional distribution of total tags and generated OTUs (Operational Taxonomic Units) grouped by phyla of fungi from all citrus root samples, through blasting against the the SILVA database.

\begin{tabular}{ccc}
\hline Phylum & OTUs & Tags \\
\hline Glomeromycota & $87(65.91 \%)$ & $613,408(99.81 \%)$ \\
Basidiomycota & $13(9.85 \%)$ & $794(0.13 \%)$ \\
Ascomycota & $8(6.06 \%)$ & $41(0.01 \%)$ \\
Chytridiomycota & $1(0.76 \%)$ & $13(0.00 \%)$ \\
unclassified & $23(17.42 \%)$ & $334(0.05 \%)$ \\
\hline
\end{tabular}

To clearly define the AMF community compositions associated with citrus roots at the species level, the clean tags were aligned to the sequences deposited in the MAARJAM database [35], which contains all the published Glomeromycota SSU rRNA gene sequences. A total of 475,917 tags $(75.46 \%$ of the total clean tags) from 18 citrus root samples were annotated to 46 virtual taxa (VT, an AMF molecular species) according to the MAARJAM database (Table S1). These 46 VT represented a high level of AMF diversity, associated with the citrus roots in a single field in a greenhouse. These $46 \mathrm{VT}$ could be further divided into four families (Table 2), including Glomeraceae (39 VT; according to 474,991 clean tags, $99.81 \%$ of the 475,917 clean tags assigned to MAARJAM database), Paraglomeraceae (3VT, 832 tags), Claroideoglomeraceae (3 VT, 88 tags) and Gigasporaceae (1VT, 6 tags). Obviously, Glomus was the dominant $\mathrm{AMF}$ family associated with citrus roots, which could be further divided into three subgroups, including Glomus group A, Glomus group B and Glomus group C (Figure 1). Notably, the three most abundant AMF species, namely, Glomus.Yamato08.A1_VTX00100 (134,970 tags, according to 28.36\% of the 475,917 clean tags assigned to the MAARJAM database), Glomus.acnaGlo2_VTX00155 (71,418, $15.01 \%)$ and Glomus.Yamato09.A2_VTX00248 (66,821, 14.04\%), were the dominant AMF species associated with citrus roots.

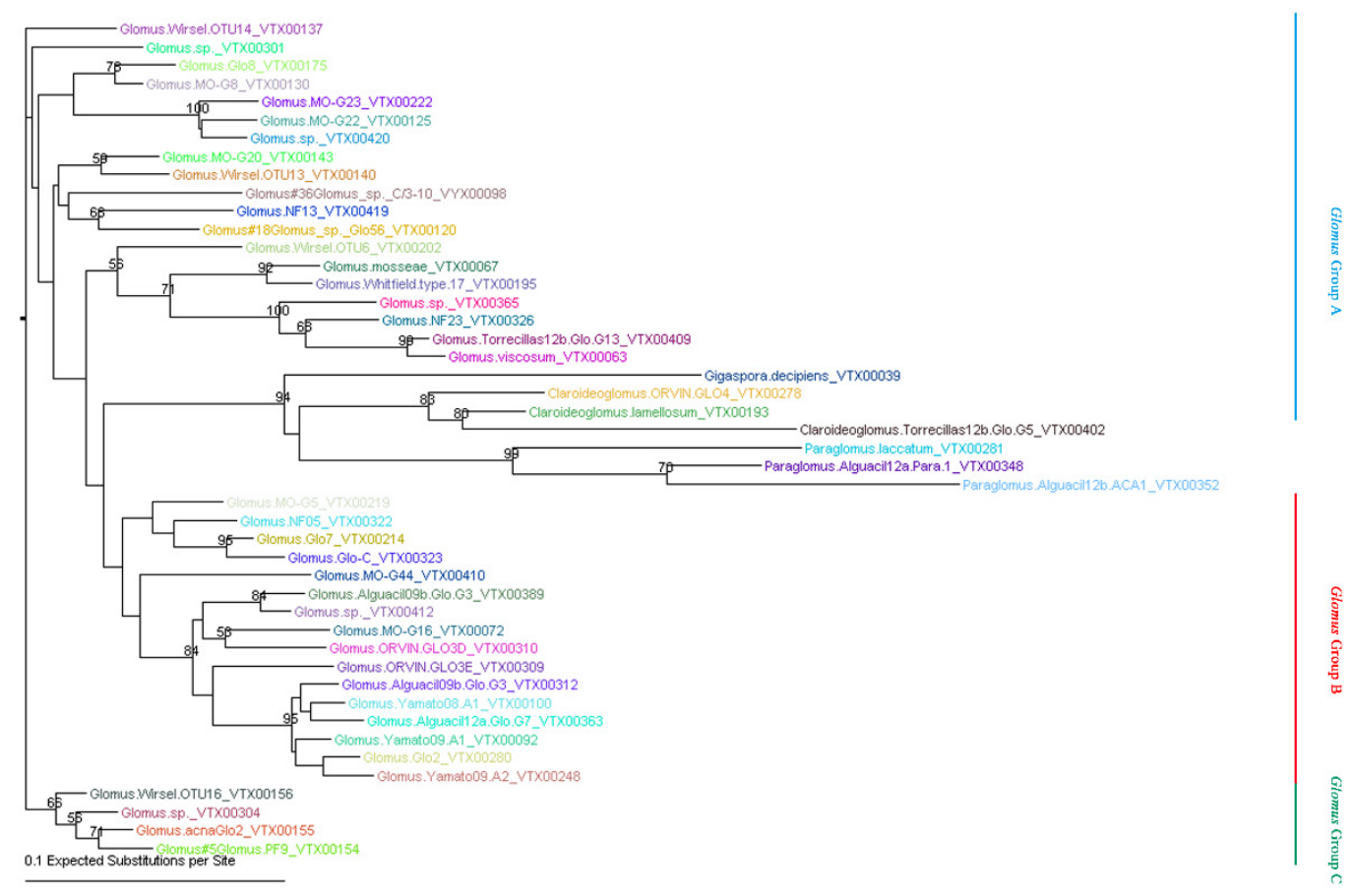

Figure 1. Neighbor-joining phylogenetic tree of AMF species detected by blasting against MAARJAM database. The F84+Gamma nucleotide substitution model was used and bootstrap values of $>50$ are shown. 
Table 2. Identification and classification of arbuscular mycorrhizal fungi (AMF) species from citrus roots in the greenhouse. AMF sequences were divided into virtual taxa through blasting against the MAARJAM database.

\begin{tabular}{|c|c|c|c|}
\hline AMF Family & AMF Species & OTU & Tags \\
\hline \multirow{39}{*}{$\begin{array}{c}\text { Glomeraceae }(39 \mathrm{VT} \text {, } \\
\text { corresponding to } 474,991 \\
\text { clean reads, accounting for } \\
99.81 \% \text { of the total }(475,917) \\
\text { clean reads against the } \\
\text { MAARJAM database) }\end{array}$} & Glomus.Yamato08.A1_VTX00100 & 2 & 134,970 \\
\hline & Glomus.acnaGlo2_VTX00155 & 3 & 71,418 \\
\hline & Glomus.Yamato09.A2_VTX00248 & 1 & 66,821 \\
\hline & Glomus.viscosum_VTX00063 & 8 & 37,975 \\
\hline & Glomus.Glo7_VTX00214 & 3 & 30,951 \\
\hline & Glomus.NF13_VTX00419 & 2 & 21,670 \\
\hline & Glomus.Torrecillas12b.Glo.G13_VTX00409 & 3 & 19,765 \\
\hline & Glomus.sp._VTX00304 & 1 & 16,515 \\
\hline & Glomus.Wirsel.OTU16_VTX00156 & 1 & 16,510 \\
\hline & Glomus.Glo-C_VTX̄̄00323 & 2 & 10,763 \\
\hline & Glomus.sp._VTTX00412 & 1 & 8217 \\
\hline & Glomus.Yamato09.A1_VTX00092 & 2 & 6499 \\
\hline & Glomus.Glo8_VTX̄o0175 & 1 & 3781 \\
\hline & Glomus.MO-G5_VTX00219 & 1 & 3736 \\
\hline & Glomus.MO-G8_VTX00130 & 1 & 3311 \\
\hline & Glomus_sp._Glo56 & 1 & 3092 \\
\hline & Glomus.MO-G44_VTX00410 & 2 & 3038 \\
\hline & Glomus.Alguacil09b.Glo.G3_VTX00389 & 1 & 2478 \\
\hline & Glomus.MO-G23_VTX00222 & 1 & 2337 \\
\hline & Glomus.sp._VTX00301 & 2 & 2292 \\
\hline & Glomus.PF9_VTX00154 & 1 & 1567 \\
\hline & Glomus_sp._C/3-10 & 2 & 1305 \\
\hline & Glomus.ORVIN.GLO3E_VTX00309 & 1 & 1290 \\
\hline & Glomus.MO-G20_VTX00143 & 1 & 1279 \\
\hline & Glomus.Alguacil09b.Glo.G3_VTX00312 & 1 & 802 \\
\hline & Glomus.NF05_VTX00322 & 1 & 657 \\
\hline & Glomus.sp._VTX00420 & 1 & 548 \\
\hline & Glomus.MO-G22_VTX00125 & 1 & 404 \\
\hline & Glomus.Alguacil12a.Glo.G7_VTX00363 & 1 & 300 \\
\hline & Glomus.NF23_VTX00326 & 2 & 260 \\
\hline & Glomus.Wirsel.OTU13_VTX00140 & 1 & 159 \\
\hline & Glomus.Glo2_VTX00280 & 1 & 96 \\
\hline & Glomus.Wirsel.OTU6_VTX00202 & 1 & 75 \\
\hline & Glomus.ORVIN.GLO3D_VTX00310 & 1 & 68 \\
\hline & Glomus.Wirsel.OTU14_VTX00137 & 2 & 17 \\
\hline & Glomus.mosseae_VTX00067 & 1 & 9 \\
\hline & Glomus.MO-G16_VTX00072 & 1 & 6 \\
\hline & Glomus.sp._VTX00365 & 1 & 5 \\
\hline & Glomus.Whitfield.type.17_VTX00195 & 1 & 5 \\
\hline \multirow{3}{*}{$\begin{array}{l}\text { Claroideoglomeraceae (3 VT, } \\
\quad 88 \text { reads, } 0.02 \%)\end{array}$} & Claroideoglomus.Torrecillas12b.Glo.G5_VTX00402 & 2 & 37 \\
\hline & Claroideoglomus.lamellosum_VTX00193 & 1 & 37 \\
\hline & Claroideoglomus.ORVIN.GLO4_VTX00278 & 2 & 14 \\
\hline \multirow{3}{*}{$\begin{array}{l}\text { Paraglomeraceae ( } 3 \mathrm{VT} \text {, } \\
832 \text { reads, } 0.17 \%)\end{array}$} & Paraglomus.Alguacil12a.Para.1_VTX00348 & 12 & 787 \\
\hline & Paraglomus.laccatum_VTX00281 & 1 & 37 \\
\hline & Paraglomus.Alguacil12b.ACA1_VTX00352 & 1 & 8 \\
\hline $\begin{array}{c}\text { Gigasporaceae (1 VT, } 6 \text { reads, } \\
0.00 \%)\end{array}$ & Gigaspora.decipiens_VTX00039 & 1 & 6 \\
\hline
\end{tabular}

\subsection{Difference in $\alpha$ Diversity of AMF Community among Different Citrus Genotypes}

To explore the effects of citrus genotypes on the compositions of the AMF communities associated with citrus roots, the $\alpha$ diversity (including species richness and genetic diversity) of the AMF communities from citrus roots under six different combinations of citrus scion/rootstock genotypes was 
assessed according to four different indices, namely, the Sobs index and Ace index (for the estimation of species richness), and the Simpson index and Shannon Index (for the estimation of genetic diversity). As shown in Table 3, the AMF richness of Orange/Poncirus was the highest, with the maximal Sobs and Ace values, and those of Orange/CitrangeCitrange were the lowest. Otherwise, the AMF diversity of different citrus genotypes was nearly in line with the AMF richness. It should be noted that a low value for the Simpson index meant a high diversity of a given AMF community, and that the Simpson value was the opposite of the Shannon value. Orange/Poncirus exhibited the highest AMF diversity, followed by Poncirus/Poncirus, Mandarin/Poncirus and Pummelo/Poncirus, whereas Orange/Citrange and Citrange/Citrange displayed the lowest AMF diversity. Interestingly, significant differences in both AMF richness and AMF diversity were observed between Orange/Citrange and Orange/Poncirus. These results indicated the potential role of rootstock genotypes in regulating the citrus root-associated AMF community richness and diversity. Additionally, the rarefaction curves were developed according to Sobs Index, in order to assess the sequencing depth of all 18 samples. As shown in Figure S2, most of the rarefaction curves reached a plateau, indicating that the sequencing depth was sufficient for AMF richness and diversity assessment.

Table 3. $\alpha$ diversity of AMF identified in citrus root samples from six scion/rootstock genotypes. AMF richness is reflected by Sobs and Ace Index, and AMF diversity is reflected by Shannon Index and Simpson Index. Data are means \pm SE. Different lowercase letters (i.e., a and $b$ ) indicate significant differences of $p<0.05$.

\begin{tabular}{ccccc}
\hline Sample & Sobs & Ace & Shannon & Simpson \\
\hline Citrange/Citrange & $55.00 \pm 2.65 \mathrm{ab}$ & $60.74 \pm 4.56 \mathrm{ab}$ & $1.79 \pm 0.2 \mathrm{~b}$ & $0.34 \pm 0.07 \mathrm{a}$ \\
Orange/Citrange & $48.33 \pm 4.26 \mathrm{~b}$ & $54.83 \pm 3.46 \mathrm{~b}$ & $1.80 \pm 0.52 \mathrm{~b}$ & $0.35 \pm 0.16 \mathrm{a}$ \\
Poncirus/Poncirus & $55.33 \pm 2.91 \mathrm{ab}$ & $59.37 \pm 3.93 \mathrm{ab}$ & $2.43 \pm 0.18 \mathrm{ab}$ & $0.15 \pm 0.04 \mathrm{ab}$ \\
Pummelo/Poncirus & $56.33 \pm 6.36 \mathrm{ab}$ & $58.56 \pm 5.99 \mathrm{ab}$ & $2.27 \pm 0.17 \mathrm{ab}$ & $0.16 \pm 0.02 \mathrm{ab}$ \\
Mandarin/Poncirus & $58.00 \pm 3.79 \mathrm{ab}$ & $64.47 \pm 5.04 \mathrm{ab}$ & $2.28 \pm 0.14 \mathrm{ab}$ & $0.15 \pm 0.03 \mathrm{ab}$ \\
Orange/Poncirus & $63.00 \pm 4.04 \mathrm{a}$ & $77.40 \pm 12.21 \mathrm{a}$ & $2.64 \pm 0.14 \mathrm{a}$ & $0.11 \pm 0.02 \mathrm{~b}$ \\
\hline
\end{tabular}

\subsection{Citrus Genotypes Shape the AMF Community Composition}

Principal coordinates analysis (PCoA) was performed based on the OTU abundance of the entire set of citrus root samples, in order to further explore the differences in AMF community composition among the different citrus genotypes. The PCoA analysis identified two components accounting for $62.14 \%$ of the total variance, which was explained by axis $1(47.06 \%)$ and by axis $2(15.08 \%)$, respectively (Figure 2). The PCoA analysis results revealed that the differences in AMF community composition among all the citrus root samples could be attributed to the genotype of the citrus rootstock. To be more specific, the AMF communities of Citrange/Citrange and Orange/Citrange obviously clustered to the right, with the same rootstock genotype, and the AMF communities of Mandarin/Poncirus, Orange/Poncirus and Pummelo/Poncirus showed clear clustering to the left with the same rootstock genotype. This result revealed that rootstock genotype played a major role in shaping the AMF community composition. To further classify the effects of the citrus scion/rootstock genotype on the AMF community's composition, we focused on two particular scion/rootstock genotype combinations: (1) Orange/Poncirus and Orange/Citrange, and (2) Orange/Citrange and Citrange/Citrange. As shown in Figure 2, Orange/Poncirus (Yellow) and Orange/Citrange (Blue), with the same scion of Newhall sweet orange grafted onto different rootstocks of Poncirus and Citrange, were clearly separated into two groups in both PC1 and PC2 axes. However, Orange/Citrange (Blue) and Citrange/Citrange (Red), with different scions of Newhall sweet orange and Citrange grafted onto the same rootstock of Citrange, were clustered together. Thus, rootstock genotype might exert a greater effect on AMF community composition than the scion genotype. 


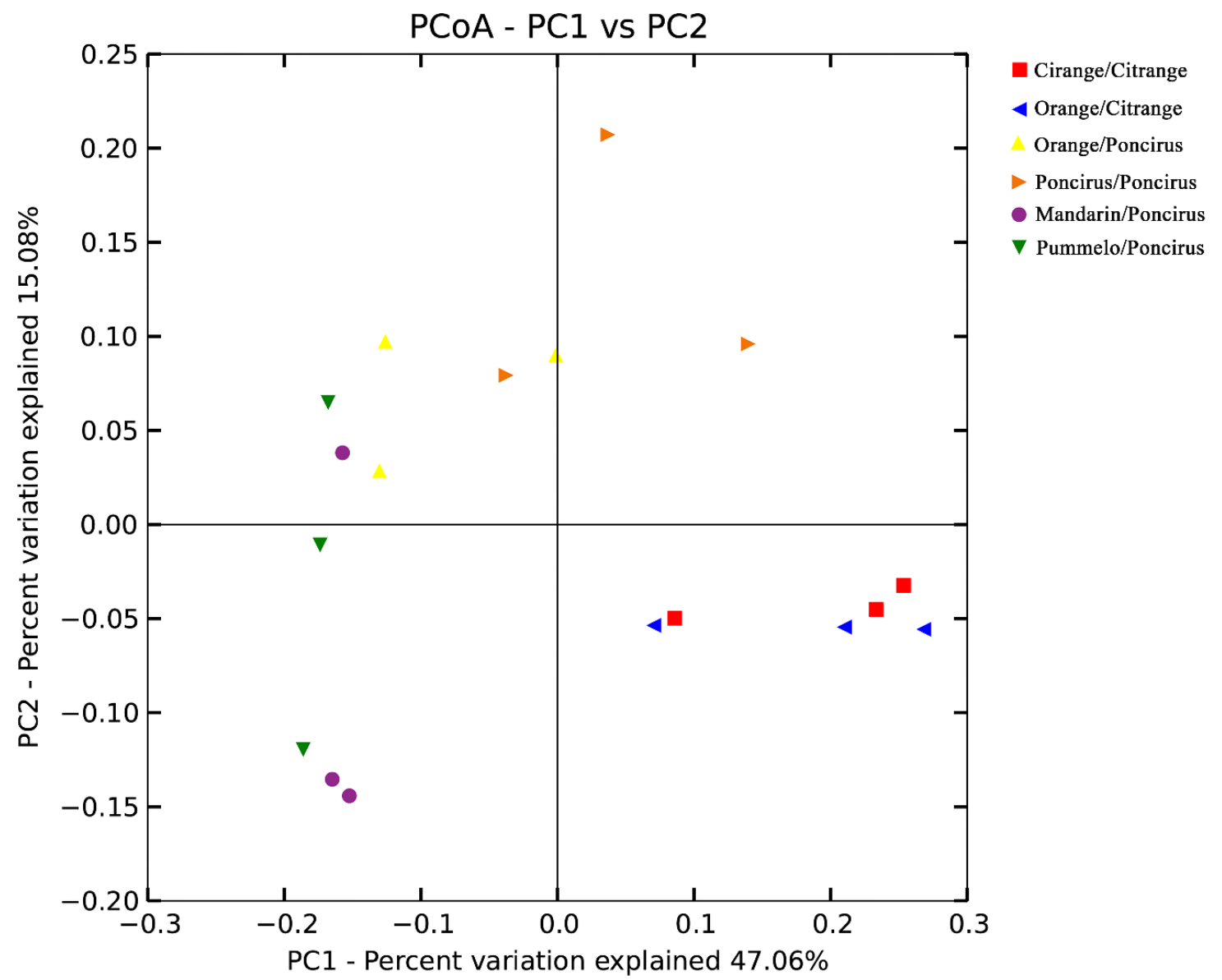

Figure 2. Principal coordinate analysis (PCoA) of variance in the citrus root-associated AMF community from six different scion/rootstock genotype combinations. Poncirus/Poncirus (Poncirus (Poncirus trifoliata) grafted onto Poncirus), Citrange/Citrange (Citrange (Citrus sinensis $\times$ Poncirus trifoliata) grafted onto Citrange), Mandarin/Poncirus (Mandarin (Citrus reticulata) grafted onto Poncirus), Pummelo/Poncirus (HB pummelo (Citrus grandis) grafted onto Poncirus), Orange/Poncirus (Newhall sweet orange (Citrus sinensis) grafted onto Poncirus) and Orange/Citrange (Newhall sweet orange grafted onto Citrange).

To further evaluate the effect of scion genotype on the AMF community, we performed PCoA analyses of the AMF community from Mandarin/Poncirus, Orange/Poncirus, Pummelo/Poncirus and Poncirus/Poncirus, with four different scions of Mandarin, Newhall sweet orange, Pummelo and Poncirus grafted onto the same rootstock of Poncirus. As shown in Figure 3, the examined samples with four different scions grafted onto the same rootstock of Poncirus were clustered into different groups, which accounted for $53.63 \%$ of the total variance in axis $1(44.36 \%)$ and axis $2(9.27 \%)$ (Figure 3$)$. To be more specific, samples of Poncirus/Poncirus (Red) were clustered in the top left, those of Mandarin/Poncirus (Orange) were clustered in the top right, while those of Orange/Poncirus (Green) and Pummelo/Poncirus (Blue) were clustered together in the bottom. These results suggested that both the scion and rootstock genotypes were able to shape the AMF community composition of the citrus roots, and that the rootstock might exert a greater impact on AMF diversity than the scion.

\subsection{Relative Abundance of AMF Species under Different Citrus Genotypes}

The difference in AMF community composition between six citrus scion/rootstock genotypes could be attributed to the diversity and richness of the AMF species. We performed a network analysis of the AMF species under different citrus genotypes. The results indicated that of all the 46 AMF species, $21(45.65 \%)$ AMF species were found to be present in all the six samples of different citrus genotypes (Figure 4). In addition, six AMF species (13.04\%) were present in only one sample. 
We also found that Glomus.MO-G16_VTX00072 was only detected in the roots of Citrange/Citrange, that Glomus.Wirsel.OTU14_VTX00137 and Paraglomus.Alguacil12b.ACA1_VTX00352 were only detected in the roots of Pummelo/Poncirus, and that Glomus.MO-G22_VTX00125, Glomus.sp._VTX00420, Glomus.MO-G23_VTX00222 and Glomus.Wirsel.OTU6_VTX00202 were only detected in the roots of Orange/Poncirus.

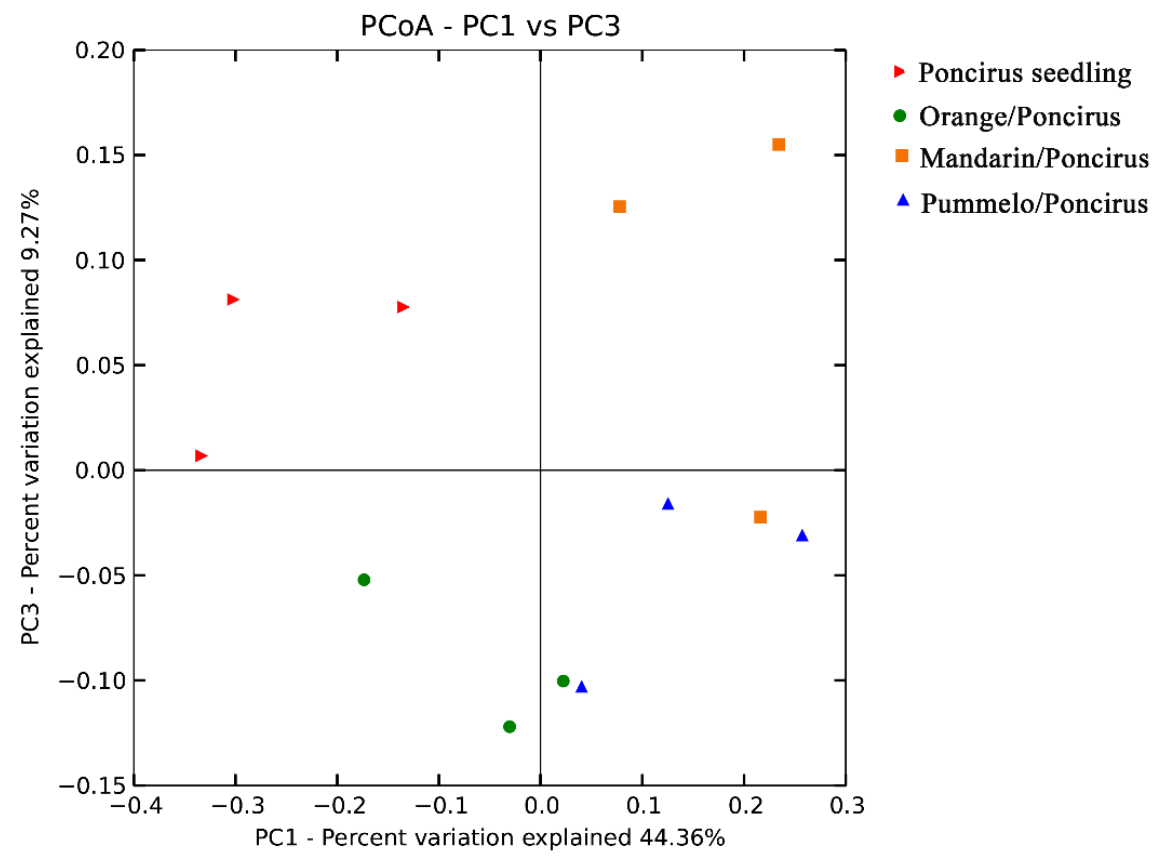

Figure 3. Principal coordinate analysis (PCoA) of variance in the citrus root-associated AMF communities from four grafted citrus plants with different scions grafted onto the same rootstock (Poncirus/Poncirus, Mandarin/Poncirus, Pummelo/Poncirus and Orange/Poncirus).

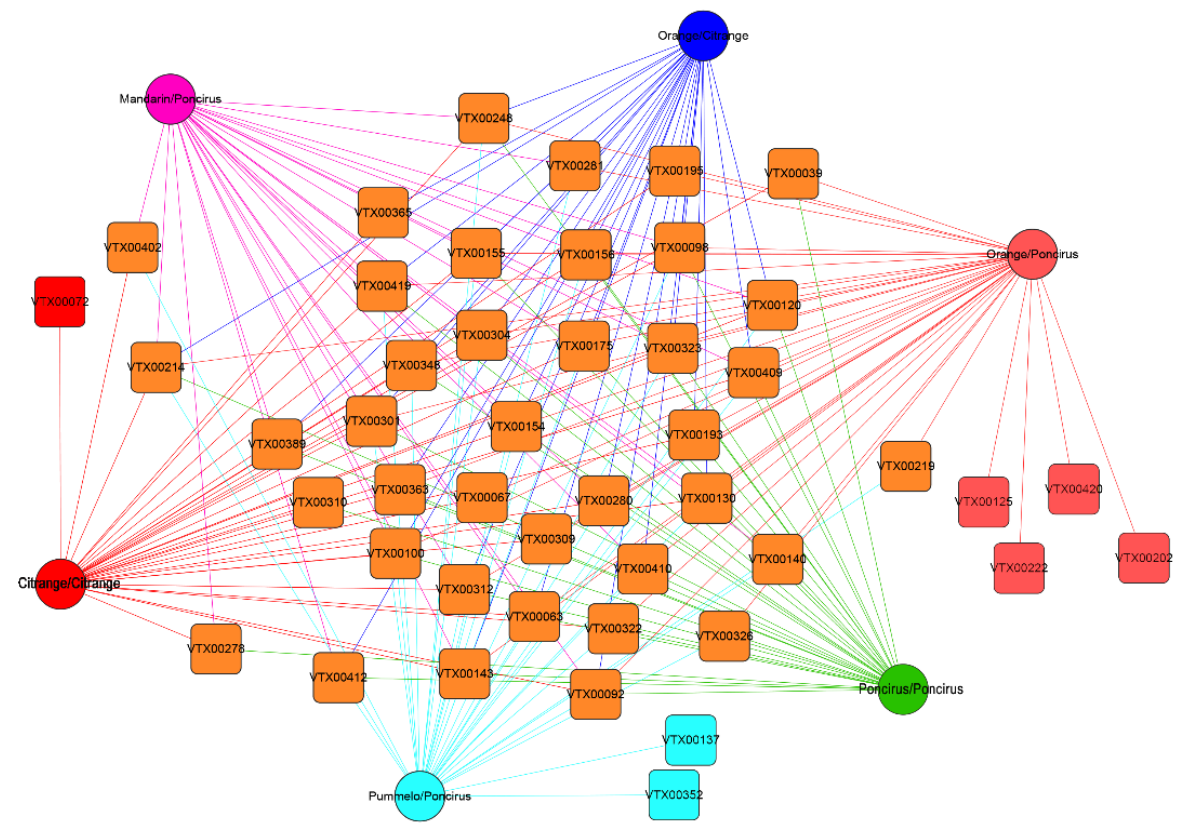

Figure 4. Networks analyses of all the root-associated AMF species from six different citrus scion/rootstock genotype combinations. AMF species which were specifically detected in one of the citrus scion/rootstock genotype combinations are highlighted in different colors, including Poncirus/Poncirus (Green), Citrange/Citrange (Red), Mandarin/Poncirus (Rose), Pummelo/Poncirus (Light Blue), Orange/Poncirus (Pink) and Orange/Citrange (Dark Blue). 
Statistical analysis indicated significant differences in the relative abundance of 15 non-specific AMF species under six different scion/rootstock genotypes (Table 4). The relative abundance of Glomus.Yamato08.A1_VTX00100 was found to be significantly higher in the samples with the same rootstock of Citrange (i.e., Citrange/Citrange and Orange/Citrange) than in the samples with rootstock of Poncirus (Poncirus/Poncirus, Pummelo/Poncirus, Mandarin/Poncirus and Orange/Poncirus). In contrast, the relative abundance of Glomus.Yamato09.A2_VTX00248 was significantly higher in the samples with the rootstock of Poncirus than in the samples with the rootstock of Citrange. Additionally, Glomus.MO-G44_VTX00410 and Glomus.NF05_VTX00322 showed a significant enrichment in Orange/Poncirus compared to the other three samples with the same rootstock but different scions.

Table 4. The relative abundance of AMF species with significant differences among six citrus scion/rootstock genotypes. Data are presented as means \pm SE. Different lowercase letters (i.e., a and $b$ ) indicate significant differences within the same row $(p<0.05)$.

\begin{tabular}{|c|c|c|c|c|c|c|}
\hline AMF Species & $\begin{array}{l}\text { Citrange/ } \\
\text { Citrange }\end{array}$ & $\begin{array}{l}\text { Orangel } \\
\text { Citrange }\end{array}$ & $\begin{array}{l}\text { Poncirus/ } \\
\text { Poncirus }\end{array}$ & $\begin{array}{l}\text { Pummelo/ } \\
\text { Poncirus }\end{array}$ & $\begin{array}{l}\text { Mandarin/ } \\
\text { Poncirus }\end{array}$ & $\begin{array}{c}\text { Orangel } \\
\text { Poncirus }\end{array}$ \\
\hline Glomus.MO-G44_VTX00410 & $0 \pm 0 \mathrm{~b}$ & $0 \pm 0 \mathrm{~b}$ & $0.05 \pm 0.05 b$ & $0.38 \pm 0.38 b$ & $0.26 \pm 0.18 b$ & $2.27 \pm 1.29 \mathrm{a}$ \\
\hline Glomus.MO-G8_VTX00130 & $0.01 \pm 0 \mathrm{~b}$ & $0 \pm 0 \mathrm{~b}$ & $0.07 \pm 0.05 b$ & $0.38 \pm 0.2 \mathrm{ab}$ & $0.47 \pm 0.27 \mathrm{ab}$ & $2.29 \pm 1.65 \mathrm{a}$ \\
\hline Glomus.sp._VTX00301 & $0.03 \pm 0.01 \mathrm{~b}$ & $0.01 \pm 0.01 b$ & $0.1 \pm 0.02 b$ & $0.74 \pm 0.26 \mathrm{ab}$ & $1.33 \pm 0.61 \mathrm{a}$ & $0.04 \pm 0.02 b$ \\
\hline Glomus.NF05_VTX00322 & $0.03 \pm 0.03 \mathrm{~b}$ & $0 \pm 0 \mathrm{~b}$ & $0.04 \pm 0.03 \mathrm{~b}$ & $0.08 \pm 0.08 \mathrm{~b}$ & $0 \pm 0 \mathrm{~b}$ & $0.49 \pm 0.25 \mathrm{a}$ \\
\hline $\begin{array}{c}\text { Paraglomus.Alguacil12a.Para.1_ } \\
\text { VTX00348 }\end{array}$ & $04+0.01 \mathrm{~b}$ & $0.06 \pm 0.01 \mathrm{~b}$ & $0.05 \pm 0.02 b$ & $0.1 \pm 0.07 \mathrm{~b}$ & $0.4 \pm 0.23 \mathrm{a}$ & $0.13 \pm 0.04 \mathrm{ab}$ \\
\hline Glomus.sp._VTX00304 & $0.18 \pm 0.06 \mathrm{~b}$ & $0.08 \pm 0.08 \mathrm{~b}$ & $0.63 \pm 0.13 \mathrm{ab}$ & $6.71 \pm 0.48 \mathrm{a}$ & $8.05 \pm 4.37 \mathrm{a}$ & $0.51 \pm 0.29 \mathrm{ab}$ \\
\hline Glomus.Wirsel.OTU16_VTX00156 & $0.21 \pm 0.09 \mathrm{~b}$ & $0.08 \pm 0.08 b$ & $0.65 \pm 0.16 b$ & $5.4 \pm 1.62 \mathrm{ab}$ & $9.29 \pm 4.52 \mathrm{a}$ & $0.5 \pm 0.26 \mathrm{~b}$ \\
\hline Glomus.ORVIN.GLO3E_VTX00309 & $0.86 \pm 0.33 \mathrm{a}$ & $0 \pm 0 \mathrm{~b}$ & $0 \pm 0 \mathrm{~b}$ & $0 \pm 0 \mathrm{~b}$ & $0 \pm 0 \mathrm{~b}$ & $0.37 \pm 0.37 \mathrm{ab}$ \\
\hline $\begin{array}{c}\text { Glomus.Torrecillas12b.Glo.G13_ } \\
\text { VTX00409 }\end{array}$ & $0.91 \pm 0.33 \mathrm{~b}$ & $0.7 \pm 0.26 b$ & $0.64 \pm 0.35 b$ & $8.15 \pm 5.2 \mathrm{a}$ & $5.83 \pm 0.66 \mathrm{ab}$ & $3.08 \pm 0.14 \mathrm{ab}$ \\
\hline Glomus.NF13_VTX00419 & $1.55 \pm 1.29 \mathrm{ab}$ & $6.74 \pm 3.42 \mathrm{ab}$ & $2.47 \pm 0.3 \mathrm{ab}$ & $2.19 \pm 0.79 \mathrm{ab}$ & $0.83 \pm 0.2 b$ & $7.79 \pm 4 \mathrm{a}$ \\
\hline Glomus.Glo-C_VTX00323 & $1.59 \pm 0.59 b$ & $0.74 \pm 0.40 \mathrm{~b}$ & $8.03 \pm 3.78 \mathrm{a}$ & $0.19 \pm 0.18 \mathrm{~b}$ & $0.02 \pm 0.01 b$ & $0.22 \pm 0.19 b$ \\
\hline Glomus.Glo7_VTX00214 & $3.04 \pm 1.14 b$ & $3.65 \pm 2.81 b$ & $15.18 \pm 7.15 \mathrm{a}$ & $2.68 \pm 2.23 b$ & $0.73 \pm 0.59 b$ & $5.34 \pm 3.88 \mathrm{ab}$ \\
\hline Glomus.Yamato09.A2_VTX00248 & $3.52 \pm 2.41 b$ & $2.75 \pm 1.38 \mathrm{~b}$ & $20.17 \pm 1.71 \mathrm{a}$ & $11.79 \pm 6.66 \mathrm{a}$ & $7.13 \pm 5.3 \mathrm{ab}$ & $20.2 \pm 5.78 \mathrm{a}$ \\
\hline Glomus.acnaGlo2_VTX00155 & $3.58 \pm 0.63 b$ & $6.61 \pm 4.42 \mathrm{~b}$ & $6.71 \pm 1.49 \mathrm{~b}$ & $27.42 \pm 4.17 \mathrm{a}$ & $12.83 \pm 5.49 \mathrm{~b}$ & $12.64 \pm 3.68 b$ \\
\hline Glomus.Yamato08.A1_VTX00100 & $54.49 \pm 8.96 \mathrm{a}$ & $50.67 \pm 17.75 \mathrm{a}$ & $19.04 \pm 10.93 b$ & $0.22 \pm 0.17 b$ & $0.05 \pm 0.01 \mathrm{~b}$ & $5.42 \pm 4.54 b$ \\
\hline
\end{tabular}

\section{Discussion}

Despite the important role of arbuscular mycorrhizal fungi (AMF) in mineral nutrient uptake for citrus plants, our understanding of the relationship between AMF and citrus remains relatively limited. In this study, we investigated the AMF community colonized in the citrus roots of six different genotypes in the greenhouse, including Poncirus/Poncirus, Citrange/Citrange, Mandarin/Poncirus, Pummelo/Poncirus, Orange/Poncirus and Orange/Citrange. We found that the genus Glomus dominated all the six samples, indicating the absolute dominance of Glomus in symbiosis with the citrus root across different citrus genotypes. Furthermore, we also revealed that the AMF community composition was affected by the citrus scion/rootstock genotype, and that the rootstock genotype of citrus might have a greater effect than the scion genotype.

To explore the effects of citrus genotypes on AMF community composition, a total of 18 root DNA samples from citrus plants grown under the same controlled condition, under six different scion/rootstock genotypes, were prepared and used for PCR amplification of the $18 \mathrm{~S}$ small subunit (SSU) rRNA gene fragment, using the highly AMF-specific primer pair AMV4.5NF/AMDGR. In this study, a total of 1,440,324 raw reads were yielded from 18 root DNA samples, of which 1,278,760 (88.78\%) were clear reads, and 46 VT (AMF species) were annotated. In the past few decades, the identification of citrus AMF species has been performed based on spore morphology [36,37]. The morphological analysis indicated that 18 AMF species belonging to five families, including Glomeraceae ( 9 species accounting for $50 \%$ ), Acaulosporaceae (4 species), Claroideoglomeraceae (2 species), Gigasporaceae (1 species) and Pacisporaceae (2 species), have been detected from the rhizosphere soil of citrus [38]. However, our study results indicated that almost $99.81 \%$ of the tags and $84.78 \%$ of the VT belonged to Glomus (the only genus of Glomeraceae), indicating an absolute dominance of the genus Glomus. This phenomenon also revealed that the AMF species of spores in the rhizosphere soil were largely different from those colonizing in the citrus roots $[39,40]$, which further implied that the selectivity 
of the plant species played an important role in the colonizing AMF community [41]. As described in previous reports, host plant species has been identified as an important factor in shaping the root-colonizing AMF community's composition [42,43]. Thus, Glomus AMF species might be recruited by citrus plants to colonize in the root cortical cells. In addition, about half of the AMF species (21 VT) were present in all the six samples of different citrus genotypes, while only six AMF species existed in a single sample, which might be attributed to the fact that all the six samples were planted in the same field in the greenhouse. Habitats were reported to have a major effect on the AMF community [44], thus the native AMF species of the Glomus genus were rapidly colonized in all the citrus seedlings.

Citrus roots have scarce root hairs, and thus they heavily rely on AMF for mineral nutrient uptake. Considering the significant role of AMF in citrus production, many studies focused on the physiological interaction and molecular signaling dialogue between root-colonizing AMF and citrus plants [45-47]. However, whether and to what degree the citrus genotype could affect the AMF community remains unclear. Our previous study indicated that the AMF community is dominantly impacted by habitat, and that citrus genotype might have a slight, but significant, effect on the AMF community composition [33. However, all the samples in the previous studies were collected from different citrus production areas in south China, and the AMF community was influenced by many field environment factors, such as soil properties, illumination, humidity, diseases and agricultural practices. Thus, in this study, we investigated the impact of the citrus scion/rootstock genotype on AMF community in a particular field in a greenhouse, with the same agricultural management, in order to exclude the interference of environment factors and agricultural practices. As was expected, the majority of samples were clustered based on different rootstock genotypes (accounting for $62.14 \%$ of the total variance, Figure 2), indicating the dominant role of citrus rootstock genotype in regulating AMF community composition. Interestingly, the further PCoA results indicated that both the scion and rootstock genotypes had a significant impact on the AMF community composition, and that the rootstock genotype might exert a greater impact than the scion genotype (Figures 2 and 3). In addition, out of six different scion/rootstock combinations, only Orange/Citrange and Orange/Poncirus, which were obtained by grafting scion Newhall sweet orange onto rootstocks Citrange and Poncirus, respectively, exhibited a significant difference in the $\alpha$ diversity (Table 3). This result indicates the potential role of rootstock genotype in regulating the community richness and diversity of AMF associated with citrus roots.

Citrus is a woody perennial plant, and it is widely planted all over the world in a form of graft. For instance, the commercial citrus cultivars Newhall sweet orange and Mandarin as scion are grafted onto the rootstocks Poncirus and Citrange, which is of significant importance for increasing the fruit's quality and its resistance to multiple biotic and abiotic stresses [48-52]. However, how scion and rootstock combinations affect the AMF community in citrus roots is still poorly understood. The previous study reported that the scion could influence the microbe's symbiosis with the rootstock through the primary and secondary metabolites [8,9,53,54], phytohormones [55], or some regulatory factors [56,57]. This study also revealed the significant impact of citrus scion genotype on the root-associated AMF community. It was reported that AMF inhabited the roots, and formed a mutualistic symbiont in the cortical cells of the citrus roots $[5,10]$. Thus, it could be speculated that rootstock genotype might exert a greater impact on the AMF community than scion genotype. This result was in line with those of similar studies on the root-associated microbiome $[31,58,59]$, but it was in opposition to those of our previous study of field condition. One possible explanation is the age of the citrus plants. In the previous study, the grafted citrus plants were more than 20 years old, and they might have modified the surrounding environment through root exudates [60,61]. However, 1-year-old juvenile citrus plants were grafted and transplanted into the greenhouse for only 1-year growth. The photosynthates synthesized from the scion (above ground part) of juvenile citrus plants were very limited [62], and less photosynthates will be translocated to the roots, since the root functions were not well recovered after transplantation into the new environment [63]. Another possible explanation lies in the different environmental conditions in different studies. As was reported, environmental factors were the dominant regulator of the AMF community [64-66]. All our samples used for assessing the impact of scion/rootstock genotype on AMF 
community were obtained from one small field in the greenhouse, but the scales of the citrus orchards in the previous studies were much larger than the greenhouse. Thus, the environmental conditions, especially the soil properties, might interfere with the effects of citrus scion/rootstock genotype on AMF community.

\section{Conclusions}

In summary, this study comprehensively analyzed AMF community composition as associated with citrus roots in a greenhouse. The AMF genus Glomus was found to be dominant in all the six samples, but different scion/rootstock genotypes specifically recruited certain AMF species from the surrounding soils. Our results indicated that AMF community composition was affected by citrus scion/rootstock genotype, and that the rootstock genotype of citrus might play a greater role than scion genotype. Further studies are needed in order to better understand the mechanisms by which grafted citrus plants shape the AMF community, and an investigation into the role of their metabolites or regulatory factors in shaping AMF communities is of great importance.

\section{Materials and Methods}

\subsection{Plant Materials and Sample Preparation}

Poncirus and Citrange seeds were generated in a sterile condition, and then transplanted into the sterile sand for one-year growth. In September of the next year, different scions were grafted onto the rootstocks. The grafted citrus plants were used for the subsequent experiment after the scions were more than $30 \mathrm{~cm}$ in length. Citrus plants with different genotypes were planted in the same field in the greenhouse to exclude the interference of environmental factors. A total of six scion/rootstock combinations of citrus cultivars were utilized to explore the effects of citrus genotype on AMF community composition, including (i) Poncirus (Poncirus trifoliata), grafted onto Poncirus and labeled Poncirus/Poncirus, (ii) Citrange (Citrus sinensis $\times$ Poncirus trifoliata), grafted onto Citrange and labeled Citrange/Citrange, (iii) Mandarin (Citrus reticulata), grafted onto Poncirus and labeled Mandarin/Poncirus, (iv) HB pummelo (Citrus grandis), grafted onto Poncirus and labeled Pummelo/Poncirus, (v) Newhall sweet orange (Citrus sinensis), grafted onto Poncirus and labeled Orange/Poncirus, and (vi) Newhall sweet orange, grafted onto Citrange and labeled Orange/Citrange (Table 5, Figure S1). After one year, a total of 18 citrus root samples were harvested for further experiments with three biological replicates for each citrus genotype.

Table 5. The description of the six grafted citrus plants with different scion/rootstock genotypes.

\begin{tabular}{|c|c|c|c|c|}
\hline Sample Name & Scion & Scion Genotype & Rootstock & Rootstock Genotype \\
\hline Poncirus/Poncirus & Poncirus & $\begin{array}{c}\text { Poncirus trifoliata } \\
\text { Citrus }\end{array}$ & Poncirus & Poncirus trifoliata \\
\hline Citrange/Citrange & Citrange & $\begin{array}{c}\text { sinensis } \times \text { Poncirus } \\
\text { trifoliata }\end{array}$ & Citrange & Citrus sinensis $\times$ Poncirus trifoliata \\
\hline Mandarin/Poncirus & Mandarin & Citrus reticulate & Poncirus & Poncirus trifoliata \\
\hline Pummelo/Poncirus & Pummelo & Citrus grandis & Poncirus & Poncirus trifoliata \\
\hline Orange/Poncirus & Newhall sweet orange & Citrus sinensis & Poncirus & Poncirus trifoliata \\
\hline Orange/Citrange & Newhall sweet orange & Citrus sinensis & Citrange & Citrus sinensis $\times$ Poncirus trifoliata \\
\hline
\end{tabular}

The root samples were processed according to a previous study with minor modifications [67]. Lateral roots were collected from the citrus samples and loose soil was removed with sterile gloves (sprayed with 70\% Ethanol). To remove the tightly attached soil, lateral roots were transferred into sterile 50-mL tubes containing $25 \mathrm{~mL}$ phosphate buffer (per litre: $6.33 \mathrm{~g}$ of $\mathrm{NaH}_{2} \mathrm{PO}_{4} \cdot \mathrm{H}_{2} \mathrm{O}, 16.5 \mathrm{~g}$ of $\mathrm{Na}_{2} \mathrm{HPO}_{4} \cdot 7 \mathrm{H}_{2} \mathrm{O}, 200 \mu \mathrm{L}$ Silwet L-77) and vortexed at a maximal speed. Buffers were refreshed until the lateral roots were totally cleaned. Subsequently, lateral roots were subjected to an ultrasonic cleaning for $10 \mathrm{~min}$ to remove the tiny soils and loose microbes on the root surface. After processing, lateral roots were frozen with liquid nitrogen and stored at $-80{ }^{\circ} \mathrm{C}$. 


\subsection{DNA Extraction, Library Construction and Sequencing}

Total DNA of the samples was extracted with a CTAB method reported previously, unique for citrus plants [68]. To construct the sequencing library, the $18 \mathrm{~S}$ small subunit regions of riboso mal RNA gene (SSU rRNA) fragments were amplified with a widely used primer pair AMV4.5NF/AMDGR [69,70] fused with two sequencing adaptors and dual index sequences. PCR products were purified and measured with LabChip GX (Caliper, USA). Subsequently, the qualified libraries were uploaded to the Illumina platform (MISeq) for sequencing by Beijing Genomics Institute (BGI, Shenzhen, China).

\subsection{Data Analysis}

After MISeq sequencing, the raw reads were screened to remove the low-quality reads, including the following: (i) the truncated sequence reads without an average quality of 20 over a 25 -bp sliding window, based on the phred algorithm, and trimmed reads with less than $75 \%$ of the original length; (ii) the reads contaminated by adaptors; (iii) the reads containing an ambiguous base; and (iv) the reads with low complexity. Then the two pair-ended clean reads were assembled into a single tag with Fast Length Adjustment of Short reads (FLASH, v1.2.11) if they were overlapped [71], and the clean reads without overlaps were removed. Subsequently, tags were clustered into OTUs based on 97\% sequence similarity, using USEARCH software [72]. The most abundant tag from each OTU was selected as the representative sequence, and the potential chimeras were identified and removed from the representative sequence with UCHIME [73].

The representative sequences were annotated to fungal OTUs against the SILVA database (v108, [34) ], and those identified as Glomeromycota sequences were further assigned to AMF species (VT, virtual taxa) against the MAARJAM database [35]. We performed a BLAST search to assign the representative sequences to the SILVA database and MAARJAM database by the following criteria: the sequence similarity was $\geq 97 \%$, and the BLAST e-value was $<1 \times 10^{-10}$.

\subsection{Phylogenetic Analysis}

For phylogenetic analysis, the representative sequences of Glomeromycota VT (the most abundant sequences of each VT) detected in all the samples were aligned using the software of the multiple sequence alignment program (MAFFT, version 7) [74]. Then, the alignment results were subjected to a neighbor-joining analysis by TOPALi (v2.5), and the phylogenetic tree was developed using the F84 model with gamma substitution rates and bootstrapping over 100 runs [75].

\subsection{Statistical Analysis}

In order to compare the diversity and richness of the AMF community under different citrus genotypes, $\alpha$ diversity (within-sample diversity or estimate of species richness) of different samples was measured. The AMF diversity indices (Shannon Index and Simpson Index) and richness indices (sbserved species and Ace Index) were measured with QIIME, as described in a previous study [70]. The rarefaction curve of all the detected samples was plotted based on the indices of Sobs using $R$ software (version 2.15.3). To clearly illustrate the effect of citrus scion/rootstock genotypes on the AMF community, the similarities between the AMF communities were calculated using a Bray-Curtis method based on the OTU abundance. A matrix of Bray-Curtis distances between the entire 18 citrus root samples was created with QIIME, and a principal coordinate analysis (PCoA) of all relevant samples, and a subgroup of such samples, was performed based on the Bray-Curtis distances. The corresponding results were plotted with R software (version 2.15.3). Different dimensions of PC1, PC2 or PC 3 were shown in the PCoA map according to the clustering of samples. The Fisher least significant difference (LSD) test of Statistical Product and Service Solutions (SPSS, [76]) were used for detecting the differentially abundant AMF species. 
Supplementary Materials: The following are available online at http://www.mdpi.com/2223-7747/9/7/901/s1, Figure S1: Configurations of six citrus scion/rootstock genotype combinations from the same field in a greenhouse, Figure S2: Rarefaction curve of Sobs Index of 18 root samples from 6 citrus scion/rootstock genotype combinations, Table S1: The absolute abundance of root-associated AMF species of six citrus scion/rootstock genotype combinations title.

Author Contributions: Conceptualization, F.S., Z.P. and Y.J.; Data curation, F.S. and L.W.; Formal analysis, F.S., F.B. and J.W.; Investigation, F.S. and J.W.; Project administration, L.W. and Y.J.; Resources, F.S. and Z.P.; Software, F.S., F.B.; Supervision, Z.P. and Y.J.; Validation, Z.P., Y.J. and L.W.; Writing: original draft, F.S.; Writing: review and editing, Z.P. and L.W. All authors have read and agreed to the published version of the manuscript.

Funding: This research was funded by the National Key R\&D Program of China (2019YFD1001400), Hubei Provincial Agriculture Research System, Hubei Provincial Characteristic Fruit Innovation, and Hubei Agricultural Science and Technology Innovation Fund (2016-620-000-001-030), Youth Science Foundation of the Hubei Academy of Agricultural Sciences (2020NKYJJ14).

Acknowledgments: Sincere gratitude goes to Professor Ping Liu from Huazhong Agriculture University, Wuhan, China, for her English editing and language polishing of the manuscript.

Conflicts of Interest: All the authors declare no conflict of interest.

\section{References}

1. Brundrett, M.C.; Tedersoo, L. Evolutionary history of mycorrhizal symbioses and global host plant diversity. New Phytol. 2018, 220, 1108-1115. [CrossRef]

2. Öpik, M.; Davison, J. Uniting species- and community-oriented approaches to understand arbuscular mycorrhizal fungal diversity. Fungal Ecol. 2016, 24, 106-113. [CrossRef]

3. Govindarajulu, M.; Pfeffer, P.E.; Jin, H.; Abubaker, J.; Douds, D.D.; Allen, J.W.; Bucking, H.; Lammers, P.J.; Shachar-Hill, Y. Nitrogen transfer in the arbuscular mycorrhizal symbiosis. Nature 2005, 435, 819-823. [CrossRef] [PubMed]

4. Harrison, M.J.; Dewbre, G.R.; Liu, J. A phosphate transporter from Medicago truncatula involved in the acquisition of phosphate released by arbuscular mycorrhizal fungi. Plant Cell 2002, 14, 2413-2429. [CrossRef] [PubMed]

5. Oldroyd, G.E.D.; Leyser, O. A plant's diet, surviving in a variable nutrient environment. Science 2020, 368. [CrossRef] [PubMed]

6. Ruiz-Lozano, J.M.; Aroca, R.; Zamarreno, A.M.; Molina, S.; Andreo-Jimenez, B.; Porcel, R.; Garcia-Mina, J.M.; Ruyter-Spira, C.; Lopez-Raez, J.A. Arbuscular mycorrhizal symbiosis induces strigolactone biosynthesis under drought and improves drought tolerance in lettuce and tomato. Plant Cell Env. 2016, 39, 441-452. [CrossRef]

7. Santander, C.; Aroca, R.; Ruiz-Lozano, J.M.; Olave, J.; Cartes, P.; Borie, F.; Cornejo, P. Arbuscular mycorrhiza effects on plant performance under osmotic stress. Mycorrhiza 2017, 27, 639-657. [CrossRef]

8. Jiang, Y.; Wang, W.; Xie, Q.; Liu, N.; Liu, L.; Wang, D.; Zhang, X.; Yang, C.; Chen, X.; Tang, D.; et al. Plants transfer lipids to sustain colonization by mutualistic mycorrhizal and parasitic fungi. Science 2017, 356, 1172-1175. [CrossRef]

9. Luginbuehl, L.H.; Menard, G.N.; Kurup, S.; Van Erp, H.; Radhakrishnan, G.V.; Breakspear, A.; Oldroyd, G.E.D.; Eastmond, P.J. Fatty acids in arbuscular mycorrhizal fungi are synthesized by the host plant. Science 2017, 356, 1175-1178. [CrossRef]

10. Smith, S.; Read, D. Mycorrhizal Symbiosis; Academic Press: Cambridge, MA, USA, 2010.

11. Davies, F.; Albrigo, L. Citrus; Acribia, S.A.: Zaragoza, Spain, 1999.

12. Rillig, M.C.; Aguilar-Trigueros, C.A.; Camenzind, T.; Cavagnaro, T.R.; Degrune, F.; Hohmann, P.; Lammel, D.R.; Roy, J.; van der Heijden, M.G.; Yang, G. Why farmers should manage the arbuscular mycorrhizal symbiosis. New Phytol. 2019, 222, 1-5. [CrossRef]

13. Srivastava, A.; Singh, S.; Marathe, R. Organic citrus: Soil fertility and plant nutrition. J. Sustain. Agric. 2002, 19, 5-29. [CrossRef]

14. Liu, L.; Hart, M.M.; Zhang, J.; Cai, X.; Gai, J.; Christie, P.; Li, X.; Klironomos, J.N. Altitudinal distribution patterns of AM fungal assemblages in a Tibetan alpine grassland. Fems Microbiol Ecol 2015, 91. [CrossRef] [PubMed] 
15. Xu, G.; Chen, H.; Shi, Z.; Liu, S.; Cao, X.; Zhang, M.; Chen, M.; Chen, J.; Xiong, K.; Yang, H. Mycorrhizal and rhizospheric fungal community assembly differs during subalpine forest restoration on the eastern Qinghai-Tibetan Plateau. Plant Soil 2019, 1-15. [CrossRef]

16. Sheldrake, M.; Rosenstock, N.P.; Revillini, D.; Olsson, P.A.; Mangan, S.; Sayer, E.J.; Wallander, H.; Turner, B.L.; Tanner, E.V. Arbuscular mycorrhizal fungal community composition is altered by long-term litter removal but not litter addition in a lowland tropical forest. New Phytol. 2017, 214, 455-467. [CrossRef]

17. Van Geel, M.; Jacquemyn, H.; Plue, J.; Saar, L.; Kasari, L.; Peeters, G.; van Acker, K.; Honnay, O.; Ceulemans, T. Abiotic rather than biotic filtering shapes the arbuscular mycorrhizal fungal communities of European seminatural grasslands. New Phytol. 2018, 220, 1262-1272. [CrossRef] [PubMed]

18. Qiang, W.; He, X.; Wang, J.; Zhao, L. Temporal and spatial variation of arbuscular mycorrhizal fungi under the canopy of Hedysarum scoparium in the northern desert, China. Appl. Soil Ecol. 2019, 136, 139-147. [CrossRef]

19. Smilauer, P.; Kosnar, J.; Kotilinek, M.; Smilauerova, M. Contrasting effects of host identity, plant community, and local species pool on the composition and colonization levels of arbuscular mycorrhizal fungal community in a temperate grassland. New Phytol. 2020, 225, 461-473. [CrossRef]

20. Williams, A.; Manoharan, L.; Rosenstock, N.P.; Olsson, P.A.; Hedlund, K. Long-term agricultural fertilization alters arbuscular mycorrhizal fungal community composition and barley (H ordeum vulgare) mycorrhizal carbon and phosphorus exchange. New Phytol. 2017, 213, 874-885. [CrossRef]

21. Davison, J.; Moora, M.; Öpik, M.; Adholeya, A.; Ainsaar, L.; Bâ, A.; Burla, S.; Diedhiou, A.; Hiiesalu, I.; Jairus, T. Global assessment of arbuscular mycorrhizal fungus diversity reveals very low endemism. Science 2015, 349, 970-973. [CrossRef]

22. Rasmussen, P.U.; Hugerth, L.W.; Blanchet, F.G.; Andersson, A.F.; Lindahl, B.D.; Tack, A.J.M. Multiscale patterns and drivers of arbuscular mycorrhizal fungal communities in the roots and root-associated soil of a wild perennial herb. New Phytol. 2018, 220, 1248-1261. [CrossRef]

23. Torrecillas, E.; Torres, P.; Alguacil, M.M.; Querejeta, J.I.; Roldan, A. Influence of habitat and climate variables on arbuscular mycorrhizal fungus community distribution, as revealed by a case study of facultative plant epiphytism under semiarid conditions. Appl Env. Microbiol 2013, 79, 7203-7209. [CrossRef] [PubMed]

24. Chaudhary, V.B.; Rua, M.A.; Antoninka, A.; Bever, J.D.; Cannon, J.; Craig, A.; Duchicela, J.; Frame, A.; Gardes, M.; Gehring, C.; et al. MycoDB, a global database of plant response to mycorrhizal fungi. Sci. Data 2016, 3, 160028. [CrossRef] [PubMed]

25. Klironomos, J.N. Variation in plant response to native and exotic arbuscular mycorrhizal fungi. Ecology 2003, 84, 2292-2301. [CrossRef]

26. Neuenkamp, L.; Moora, M.; Opik, M.; Davison, J.; Gerz, M.; Mannisto, M.; Jairus, T.; Vasar, M.; Zobel, M. The role of plant mycorrhizal type and status in modulating the relationship between plant and arbuscular mycorrhizal fungal communities. New Phytol. 2018, 220, 1236-1247. [CrossRef]

27. Lopez-Garcia, A.; Varela-Cervero, S.; Vasar, M.; Opik, M.; Barea, J.M.; Azcon-Aguilar, C. Plant traits determine the phylogenetic structure of arbuscular mycorrhizal fungal communities. Mol Ecol 2017, 26, 6948-6959. [CrossRef]

28. Verbruggen, E.; Kuramae, E.E.; Hillekens, R.; de Hollander, M.; Kiers, E.T.; Roling, W.F.; Kowalchuk, G.A.; van der Heijden, M.G. Testing potential effects of maize expressing the Bacillus thuringiensis Cry $1 \mathrm{Ab}$ endotoxin (Bt maize) on mycorrhizal fungal communities via DNA- and RNA-based pyrosequencing and molecular fingerprinting. Appl. Env. Microbiol. 2012, 78, 7384-7392. [CrossRef]

29. Ribeiro, R.V.; Espinoza-Núñez, E.; Junior, J.P.; Mourão Filho, F.A.; Machado, E.C. Citrus rootstocks for improving the horticultural performance and physiological responses under constraining environments. In Improvement of Crops in the Era of Climatic Changes; Springer: Berlin, Germany, 2014; pp. 1-37.

30. Bowman, K.D.; McCollum, G. Five new citrus rootstocks with improved tolerance to huanglongbing. HortScience 2015, 50, 1731-1734. [CrossRef]

31. Marasco, R.; Rolli, E.; Fusi, M.; Michoud, G.; Daffonchio, D. Grapevine rootstocks shape underground bacterial microbiome and networking but not potential functionality. Microbiome 2018, 6, 3. [CrossRef]

32. Ling, N.; Song, Y.; Raza, W.; Huang, Q.; Guo, S.; Shen, Q. The response of root-associated bacterial community to the grafting of watermelon. Plant. Soil 2015, 391, 253-264. [CrossRef] 
33. Song, F.; Pan, Z.; Bai, F.; An, J.; Liu, J.; Guo, W.; Bisseling, T.; Deng, X.; Xiao, S. The Scion/Rootstock Genotypes and Habitats Affect Arbuscular Mycorrhizal Fungal Community in Citrus. Front. Microbiol. 2015, 6, 1372. [CrossRef]

34. Quast, C.; Pruesse, E.; Yilmaz, P.; Gerken, J.; Schweer, T.; Yarza, P.; Peplies, J.; Glöckner, F.O. The SILVA ribosomal RNA gene database project: Improved data processing and web-based tools. Nucleic Acids Res. 2012, 2012, gks1219. [CrossRef]

35. Öpik, M.; Vanatoa, A.; Vanatoa, E.; Moora, M.; Davison, J.; Kalwij, J.; Reier, Ü.; Zobel, M. The online database MaarjAM reveals global and ecosystemic distribution patterns in arbuscular mycorrhizal fungi (Glomeromycota). New Phytol. 2010, 188, 223-241. [CrossRef] [PubMed]

36. Nemec, S.; Menge, J.; Platt, R.; Johnson, E. Vesicular: Arbuscular mycorrhizal fungi associated with citrus in Florida and California and notes on their distribution and ecology. Mycologia 1981, 112-127.

37. Wang, P.; Shu, B.; Wang, Y.; Zhang, D.; Liu, J.; Xia, R. Diversity of arbuscular mycorrhizal fungi in red tangerine (Citrus reticulata Blanco) rootstock rhizospheric soils from hillside citrus orchards. Pedobiologia 2013, 56, 161-167. [CrossRef]

38. Wang, P.; Zhang, J.J.; Shu, B.; Xia, R.X. Arbuscular mycorrhizal fungi associated with citrus orchards under different types of soil management, southern China. Plant. Soil Env. 2012, 58, 302-308. [CrossRef]

39. Faggioli, V.S.; Cabello, M.N.; Grilli, G.; Vasar, M.; Covacevich, F.; Öpik, M. Root colonizing and soil borne communities of arbuscular mycorrhizal fungi differ among soybean fields with contrasting historical land use. Agric. Ecosyst. Environ. 2019, 269, 174-182. [CrossRef]

40. Saks, Ü.; Davison, J.; Öpik, M.; Vasar, M.; Moora, M.; Zobel, M. Root-colonizing and soil-borne communities of arbuscular mycorrhizal fungi in a temperate forest understorey. Botany 2014, 92, 277-285. [CrossRef]

41. Davison, J.; Moora, M.; Jairus, T.; Vasar, M.; Öpik, M.; Zobel, M. Hierarchical assembly rules in arbuscular mycorrhizal (AM) fungal communities. Soil Biol. Biochem. 2016, 97, 63-70. [CrossRef]

42. Martínez-García, L.B.; Richardson, S.J.; Tylianakis, J.M.; Peltzer, D.A.; Dickie, I.A. Host identity is a dominant driver of mycorrhizal fungal community composition during ecosystem development. New Phytol. 2015, 205, 1565-1576. [CrossRef]

43. Krüger, C.; Kohout, P.; Janoušková, M.; Püschel, D.; Frouz, J.; Rydlová, J. Plant communities rather than soil properties structure arbuscular mycorrhizal fungal communities along primary succession on a mine spoil. Front. Microbiol. 2017, 8, 719. [CrossRef]

44. Landis, F.C.; Gargas, A.; Givnish, T.J. Relationships among arbuscular mycorrhizal fungi, vascular plants and environmental conditions in oak savannas. New Phytol. 2004, 164, 493-504. [CrossRef]

45. An, J.; Sun, M.; van Velzen, R.; Ji, C.; Zheng, Z.; Limpens, E.; Bisseling, T.; Deng, X.; Xiao, S.; Pan, Z. Comparative transcriptome analysis of Poncirus trifoliata identifies a core set of genes involved in arbuscular mycorrhizal symbiosis. J. Exp. Bot 2018, 69, 5255-5264. [CrossRef] [PubMed]

46. Gao, X.; Zhao, S.; Xu, Q.-L.; Xiao, J.-X. Transcriptome responses of grafted Citrus sinensis plants to inoculation with the arbuscular mycorrhizal fungus Glomus versiforme. Trees 2016, 30, 1073-1082. [CrossRef]

47. Zou, Y.-N.; Wang, P.; Liu, C.-Y.; Ni, Q.-D.; Zhang, D.-J.; Wu, Q.-S. Mycorrhizal trifoliate orange has greater root adaptation of morphology and phytohormones in response to drought stress. Sci. Rep. 2017, 7, 1-10. [CrossRef]

48. Wu, J.; Cao, J.; Su, M.; Feng, G.; Xu, Y.; Yi, H. Genome-wide comprehensive analysis of transcriptomes and small RNAs offers insights into the molecular mechanism of alkaline stress tolerance in a citrus rootstock. Hortic. Res. 2019, 6, 1-19. [CrossRef]

49. Tan, F.-Q.; Tu, H.; Liang, W.-J.; Long, J.-M.; Wu, X.-M.; Zhang, H.-Y.; Guo, W.-W. Comparative metabolic and transcriptional analysis of a doubled diploid and its diploid citrus rootstock (C. junos cv. Ziyang xiangcheng) suggests its potential value for stress resistance improvement. BMC Plant Biol. 2015, 15, 89. [CrossRef] [PubMed]

50. Pedroso, F.K.; Prudente, D.A.; Bueno, A.C.R.; Machado, E.C.; Ribeiro, R.V. Drought tolerance in citrus trees is enhanced by rootstock-dependent changes in root growth and carbohydrate availability. Environ. Exp. Bot. 2014, 101, 26-35. [CrossRef]

51. Albrecht, U.; Fiehn, O.; Bowman, K.D. Metabolic variations in different citrus rootstock cultivars associated with different responses to Huanglongbing. Plant. Physiol. Biochem. 2016, 107, 33-44. [CrossRef]

52. Benjamin, G.; Tietel, Z.; Porat, R. Effects of rootstock/scion combinations on the flavor of citrus fruit. J. Agric. Food Chem. 2013, 61, 11286-11294. [CrossRef] 
53. Broeckling, C.D.; Broz, A.K.; Bergelson, J.; Manter, D.K.; Vivanco, J.M. Root exudates regulate soil fungal community composition and diversty. Appl Env. Microb 2008, 74, 738-744. [CrossRef]

54. Micallef, S.A.; Shiaris, M.P.; Colon-Carmona, A. Influence of Arabidopsis thaliana accessions on rhizobacterial communities and natural variation in root exudates. J. Exp. Bot 2009, 60, 1729-1742. [CrossRef] [PubMed]

55. Lebeis, S.L.; Paredes, S.H.; Lundberg, D.S.; Breakfield, N.; Gehring, J.; McDonald, M.; Malfatti, S.; Glavina del Rio, T.; Jones, C.D.; Tringe, S.G.; et al. PLANT MICROBIOME. Salicylic acid modulates colonization of the root microbiome by specific bacterial taxa. Science 2015, 349, 860-864. [CrossRef] [PubMed]

56. Krusell, L.; Madsen, L.H.; Sato, S.; Aubert, G.; Genua, A.; Szczyglowski, K.; Duc, G.; Kaneko, T.; Tabata, S.; de Bruijn, F.; et al. Shoot control of root development and nodulation is mediated by a receptor-like kinase. Nature 2002, 420, 422-426. [CrossRef] [PubMed]

57. Nishimura, R.; Hayashi, M.; Wu, G.J.; Kouchi, H.; Imaizumi-Anraku, H.; Murakami, Y.; Kawasaki, S.; Akao, S.; Ohmori, M.; Nagasawa, M.; et al. HAR1 mediates systemic regulation of symbiotic organ development. Nature 2002, 420, 426-429. [CrossRef]

58. Poudel, R.; Jumpponen, A.; Kennelly, M.M.; Rivard, C.L.; Gomez-Montano, L.; Garrett, K.A. Rootstocks shape the rhizobiome: Rhizosphere and endosphere bacterial communities in the grafted tomato system. Appl. Env. Microbiol. 2019, 85, e01765-18. [CrossRef]

59. Liu, J.; Abdelfattah, A.; Norelli, J.; Burchard, E.; Schena, L.; Droby, S.; Wisniewski, M. Apple endophytic microbiota of different rootstock/scion combinations suggests a genotype-specific influence. Microbiome 2018, 6, 18. [CrossRef]

60. Singh, G.; Mukerji, K.G. Root exudates as determinant of rhizospheric microbial biodiversity. In Microbial Activity in the Rhizoshere; Springer: Berlin, Germany, 2006; pp. 39-53.

61. Hugoni, M.; Luis, P.; Guyonnet, J.; el Zahar Haichar, F. Plant host habitat and root exudates shape fungal diversity. Mycorrhiza 2018, 28, 451-463. [CrossRef]

62. Jach, M.; Ceulemans, R. Effects of season, needle age and elevated atmospheric CO2 on photosynthesis in Scots pine (Pinus sylvestris). Tree Physiol. 2000, 20, 145-157. [CrossRef]

63. Shiroya, T.; Lister, G.; Krotkov, G.; Nelson, C.; Slankis, V. Translocation of the products of photosynthesis to roots of pine seedlings. Can. J. Bot. 1962, 40, 1125-1135. [CrossRef]

64. Hazard, C.; Gosling, P.; Van Der Gast, C.J.; Mitchell, D.T.; Doohan, F.M.; Bending, G.D. The role of local environment and geographical distance in determining community composition of arbuscular mycorrhizal fungi at the landscape scale. ISME J. 2013, 7, 498-508. [CrossRef]

65. Vieira, L.C.; Silva, D.K.A.d.; Escobar, I.E.C.; Silva, J.M.d.; Moura, I.A.d.; Oehl, F.; Silva, G.A.d. Changes in an Arbuscular Mycorrhizal Fungi Community Along an Environmental Gradient. Plants 2020, 9, 52. [CrossRef]

66. Xu, X.; Chen, C.; Zhang, Z.; Sun, Z.; Chen, Y.; Jiang, J.; Shen, Z. The influence of environmental factors on communities of arbuscular mycorrhizal fungi associated with Chenopodium ambrosioides revealed by MiSeq sequencing investigation. Sci. Rep. 2017, 7, 45134. [CrossRef] [PubMed]

67. Lundberg, D.S.; Lebeis, S.L.; Paredes, S.H.; Yourstone, S.; Gehring, J.; Malfatti, S.; Tremblay, J.; Engelbrektson, A.; Kunin, V.; del Rio, T.G.; et al. Defining the core Arabidopsis thaliana root microbiome. Nature 2012, 488, 86-90. [CrossRef] [PubMed]

68. Cheng, Y.-J.; Guo, W.-W.; Yi, H.-L.; Pang, X.-M.; Deng, X. An efficient protocol for genomic DNA extraction from Citrus species. Plant. Mol. Biol. Report. 2003, 21, 177-178. [CrossRef]

69. Lumini, E.; Orgiazzi, A.; Borriello, R.; Bonfante, P.; Bianciotto, V. Disclosing arbuscular mycorrhizal fungal biodiversity in soil through a land-use gradient using a pyrosequencing approach. Environ. Microbiol. 2010, 12, 2165-2179. [CrossRef] [PubMed]

70. Lin, X.; Feng, Y.; Zhang, H.; Chen, R.; Wang, J.; Zhang, J.; Chu, H. Long-term balanced fertilization decreases arbuscular mycorrhizal fungal diversity in an arable soil in North China revealed by 454 pyrosequencing. Environ. Sci. Technol. 2012, 46, 5764-5771. [CrossRef]

71. Magoč, T.; Salzberg, S.L. FLASH: Fast length adjustment of short reads to improve genome assemblies. Bioinformatics 2011, 27, 2957-2963. [CrossRef]

72. Edgar, R.C. UPARSE: Highly accurate OTU sequences from microbial amplicon reads. Nat. Methods 2013, 10, 996-998. [CrossRef]

73. Edgar, R.C.; Haas, B.J.; Clemente, J.C.; Quince, C.; Knight, R. UCHIME improves sensitivity and speed of chimera detection. Bioinformatics 2011, 27, 2194-2200. [CrossRef] 
74. Katoh, K.; Misawa, K.; Kuma, K.i.; Miyata, T. MAFFT: A novel method for rapid multiple sequence alignment based on fast Fourier transform. Nucleic Acids Res. 2002, 30, 3059-3066. [CrossRef]

75. Milne, I.; Wright, F.; Rowe, G.; Marshall, D.F.; Husmeier, D.; McGuire, G. TOPALi: Software for automatic identification of recombinant sequences within DNA multiple alignments. Bioinformatics 2004, 20, 1806-1807. [CrossRef] [PubMed]

76. Holzer, C.; Precht, M. Multiple comparison procedures for normally distributed ANOVA models in SAS, SPSS, BMDP, and MINITAB. Computation Stat 1992, 13, 351-358. [CrossRef]

(C) 2020 by the authors. Licensee MDPI, Basel, Switzerland. This article is an open access article distributed under the terms and conditions of the Creative Commons Attribution (CC BY) license (http://creativecommons.org/licenses/by/4.0/). 